\title{
Space, time and group identity in Jubilees 8-9
}

\author{
Pieter M Venter \\ Department of Old Testament Science \\ University of Pretoria
}

\begin{abstract}
Jubilees 8-9 is a rewriting of Genesis 10. It changed a depiction of Israel's identity in genealogical terms into one using spatial terms. This ideological construct was based on a Noah tradition and on Biblical texts describing the ideal borders of the land allotted to Israel. Using a triad of space, time and identity the author of Jubilees advanced his conviction of who the true Israel was. He emphasized the holiness of their land and demarcated the borders of the territory that God allotted them.
\end{abstract}

\section{INTRODUCTION}

The Book of Jubilees retells the narrative of Genesis to Exodus 19. This pseudepigraphical book apparently aimed at theologizing this section of the Bible to address the community that constituted its audience (cf Endres 1987:226). The author used a pre-Masoretic text ${ }^{1}$ and applied different techniques, such as choosing key points, creating omissions, inserting transformations, filling in halakhic interpolations, adding material, freely condensing, expurgating, explaining, supplementing and sometimes radically recasting the biblical episodes (cf Wintermute 1988:35).

The author of Jubilees sharply abbreviated the biblical account of the flood (Gn 6:1-9:28) in his Noah section (Jub 2-10). He also inserted a considerable amount of extra biblical material in this section (cf Wintermute 1988:36). He included additional material on the judgment of the watchers (5:6-16), the feast of weeks (6:17-22), the calendar (6:23-28), the testament of Noah (7:20-39), the division of the world (8:10-9:15), Noah's effective

\footnotetext{
${ }^{1}$ James C VanderKam (1977:136) states that "Jub. offers unmistakable evidence that its author used a Palestinian biblical text as the basis for his composition". VanderKam (1977:137) also remarks "that one should not look to the MT or proto-MT as the source of Jub.'s material. Rather, its text was at home in Palestine". The author of Jub. quoted from and alluded to an early Palestinian Bible. He used "a Palestinian biblical tradition" (VanderKam 1977:138).
} 
intersession against Mastema (10:1-4), and Canaan's occupation of land belonging to Israel (10:28-34).

The section Jubilees 8:11-9:15 represents the author's theological rephrasing of the list of Noah's descendants in Genesis 10:1-32. The most obvious change to the Genesis material is the shift from mainly genealogical concepts to overwhelming spatial concepts. This re-conceptualization gives a clear indication of the spatial orientated ideology ${ }^{2}$ of the author of Jubilees.

This paper investigates this change in communication strategy and aims at showing how the author of Jubilees conveyed his ideology on the identity of his group by using spatial conceptualisations along with his particular chronological scheme of jubilee units.

\section{GENESIS 10}

Genesis 10:1-32 presents a list of nations. This follows upon the notice of Noah's death (Gn 9:18-29) and precedes the Tower of Babel narrative (Gn 11:1-9). According to VanderKam's (2000:481) analysis this list contains J(Gn 10:1b, 8-19,3 21, 25-30) as well as P- (Gn 10:1a, 2-7, 20, 22-23, 31-32) material. It presents a genealogy of the sons of Noah and links his offspring to different geographical areas. ${ }^{4}$ God's command at the creation of the world to populate the earth has come to realisation and now the distribution of the related peoples of the earth is mapped out.

In the rest of the book of Genesis it is this genealogical aspect that is further exploited rather than the geographical distribution of the people of the earth. Israel's identity is spelled out in genealogical terms. The heading "generations" (Hebrew: toledot) of the list in Genesis 10 links it to the larger genealogical structure of the priestly work (Gn 2:4b; $5: 1 ; 6: 9 ; 11: 10,27 ; 25: 12$, $19 ; 36: 1,4,9 ; 37: 2 ; \mathrm{Nm} \mathrm{3:1)}$. Steinberg (1993) indicated that the main theme in the remainder of the book of Genesis is that of genealogy. The genealogy of Shem in Genesis 11:10-26 tapers down to the genealogy of Terah in Genesis 11:27-32. The chapters that follow (Gn 12-50) are dedicated to the

\footnotetext{
${ }^{2}$ Philip S Alexander stated that "our images of the world can be extraordinarily revealing about our mentality" (quoted in Scott 2002:1-2). Not only man's relationship to time, but also his orientation towards and organisation of space, as revealed in his ideas about the geographical world, should be studied (cf Scott 2002:2).

${ }^{3}$ Although most of the names in the genealogy can be linked to the names of areas in the world, only verse 19 provides geographical information of a territory. It is to this type of information that Jubilees links his depiction of the world. As this is $\mathrm{J}$ material the question can be asked whether Jubilees gave preference to the material we assign to the Yahwist or not?

${ }^{4}$ This linking of descendants to territories is also known from the mappa mundi (BM 92687) in the Babylon cuneiform literature from the seventh or sixth centuries BCE. In the Babylonian mappa mundi a schematic map is used in an effort to describe the world. It clearly served a political end (cf VanderKam 2000:476).
} 
offspring of Terah. These chapters comprise of three narrative cycles in which the triad "heir ship, marriage and ownership of land" (Steinberg 1993:135) plays the central role. In the Sarah-Hagar cycle (Gn 11:10-25:11) a marriage of polycoity (cf Steinberg 1993:152) assures Abraham of offspring who can inherit the land God gave to him. In the Rebecca cycle (Gn 25:12-35:29) a monogamous marriage sees to the continuation of the genealogy of Isaac and to an heir to his land. In the Leah-Rachel cycle (Gn 36:1-50:26) a marriage of sororal polygyny (Steinberg 1993:152) brings a horizontal lineage of twelve brothers and one sister who temporarily forfeit the land to go down and live in Egypt.

Steinberg (1993:147) comes to the conclusion that " $[$ t]he three narrative cycles together provide a means to connect those who were removed from the land (the Lea-Rachel cycle) with those who remained in the land after the Babylonian defeat (the Sara-Hagar and Rebekah cycles)". Priority is, however, given to those who were removed from the land. In the exile the "true" Israel came into existence. These texts "reflect an ideology whereby kinship relationship expressed through genealogies is used as metaphors for understanding the socio-political relationship in the postexilic community. The true Israel is a family of brothers who can trace their ancestry back to the vertical patrilineage of Terah" (Steinberg 1993:147). Thus group identity in the post exilic community is conceptualised in terms of genealogy, while marriage and living in the land are variable themes refining the meaning of kinship.

In the lists found in 1 Chronicles 1:1-9:44 genealogy is also used as means to identify the "true" Israel, those who belong to the temple community in Jerusalem.

In Jubilees 8-9's rendering of Genesis, genealogy gives way to land as the main concept. Kinship relationship and therefore the identity of Israelite society are now conceptualized in terms of space, of the holy territory and its eternally fixed borders allotted to Israel. Occupation of this land moves between creation and restoration in the final jubilee of Jubilees' chronological scheme. Jubilees use space and time in stead of genealogy to portray the identity of the true Israel.

\section{THE WORLD IN JUBILEES 8-9}

The table of Genesis 10 often served as model for representing the world and its inhabitants. It was used in different interpretations of Genesis (such as 1 Chr 1:4-23), in Jubilees 8-9, in the Genesis Apocryphon 12-17 (in very fragmentary form), in Josephus' Antiquities 1.109-39 (especially 1.122-39), and also in Pseudo Philo's Liber Antiquitatum Biblicarum 4(-5) (cf VanderKam 2000:477). 


\section{Space, time and group identity in Jubilees 8-9}

Jubilees' rendition of Genesis 10 in his chapters 8:11-9:15 can be studied in (a) the Ethiopic version, consisting of the entire text of Jubilees5 (b) citations from certain chapters in an anonymous Syriac chronicle (such as 8:24, 11-12, 22-27, 29-30; 10:29) and (c) citations from the chapters in the writings of several Greek authors. ${ }^{6}$ Unfortunately none of the fragmentary copies found among the Dead Sea Scrolls retain any part of chapters 8-10.

When the author of Jubilees changed the genealogical list in Genesis 10:1-32 into a geographical description of the nations and their territories in Jubilees 8:10-9:15 he reproduces the Hebrew names in Genesis without changing them. He also uses names not found in the biblical text. The way Genesis 10:19 defines the land of Canaan as the territory within the SidonGaza-Lasha triangle probably served as model for Jubilees to indicate the habitat of the nations according to the boundaries of their geographical areas. Jubilees proceeds according to the four points of the compass to describe the three main areas of the world allocated to Shem, Ham and Japhet. He lists these areas from north to south (Lebanon to Egypt) and from east to west (Lebanon to the sea coast). Each area is indicated by describing the boundaries of that specific area.

Jubilees 8-9 consists of two interrelated parts. In the first part (Jub 8:10-30) Noah divides the earth by lot amongst his three sons Shem, Ham and Japhet. The order of their names is the same as the order in Genesis 10:1 indicating a north to south, east to west line. In the second part (Jub 9:115) Noah's sons, in the presence of their father, subdivides their portions among their own sons. Jubilees now follows the order Ham, Shem and Japhet. This is the reversed order of Japheth (Gn 10:2-5), Ham (Gn 10:6-20) and Shem (Gn 10:21-31) in Genesis. The direction is now from south to north. In this way the whole world is covered twice, first by three major lines of demarcation and then by smaller subdivisions. While the grandsons appear directly after listing each son of Noah in Genesis 10, Jubilees 8-9 contains separate sections for the sons and the grandsons and provide explicit geographical boundaries between them. ${ }^{7}$

In the first section (Jub 8:10-30) the scene is depicted where Noah divides the earth between his sons. Describing the allotted portions and boundaries of each in great detail, Jubilees follows a circular path. The

\footnotetext{
${ }^{5}$ Scott (2002:28) indicates that this Ethiopic version containing Jub 8:11-9:15 is a translation of a lost Greek version.

${ }^{6}$ Cedrenus, Historiarum Compendium for 8:2-3; 10:15; Syncellus, Chronographia for 10:1, 3, 7-9; Theodosius of Miletus for 10:29-31, 34.

${ }^{7}$ This procedure in Jubilees agrees with the later geographic work of Dionysius Periegetis of Alexandria written during the reign of Hadrian (117-138 CE) (cf Scott 2002:32).
} 
territories of Shem and Japhet, however, are depicted in a counter clockwise circuit beginning at the source of the Tina River. Ham's territory is described in a clockwise circuit beginning at a place beyond the Gihon River to the right of the Garden of Eden. Each description ends with the same type of formula, declaring that the portion allotted to a specific son became the possession of that person as well as his descendants.

In the second section (9:1-15) the subdivision between the grandchildren and the boundaries of their respective areas are set out. Noah puts them under oath to keep to these allotted boundaries.

Shem receives the most favourable portion of all in the centre of the earth (Jub 8:12-21), Ham the hot southern portion and Japhet the cold northern section. ${ }^{8}$ Compared to other sections of the book of Jubilees it seems as if Jubilees expects the descendants of Shem to rule the world from their privileged position in the centre of the earth. The blessing of Abraham for Jacob in Jubilees 22:11-14 puts them in the centre of the earth making all bow down before them because they possess the whole earth. Jacob's descendants are granted universal sovereignty in Jubilees 19:21-22 and 32:18-19. The privileged position of Shem's territory is also indicated by the presence of all four holy places in his territory (Garden of Eden, Mount Sinai, Mount Zion and the Mountain of the East).

\section{THE WORLD MAP OF JUBILEES}

The graphical world map presented in Jubilees 8:10-9:15 uses two categories of spatial orientation. First, the world depicted here consists of three areas or regions named after the son's of Noah. Preference is given to the area of Shem where the above mentioned four holy places are found. Secondly, each area is described in terms of its borders. It can be accepted that this reflects the geographical knowledge in the time of the author. He uses that knowledge to convey his view on the offspring of Shem, that is the Israelites. In modern research it was believed that this map can be reconstructed to further our understanding of the book. Unfortunately neither the exact boundaries of the ethnic territories in Genesis 10:1-32, nor any recognisable place names are given in Jubilees 8:10-9:15. This invited geographical speculation and allowed revision of these theories in the course of time (cf Scott 2002:25).

At least four different proposals have been published by Holscher (1944), M Testuz (1960), Philip S Alexander, and F Schmidt (cf VanderKam

\footnotetext{
${ }^{8}$ In the Greek geographical models the zones of the world are also divided according to climate zones (cf Scott 2002:33).
} 


\section{Space, time and group identity in Jubilees 8-9}

2000:494-495). Comparing Jubilees' description of the world to contemporary Ionian maps, both Holscher and Alexander found a similar division into three world zones with two parallel rivers. Although Jubilees 8-9 could have given us some insight into Jewish cartographic actions during the Second Temple period (cf Scott 2002:1), no real progress was made in regaining sufficient information on this activity.

According to Wintermute (1988:45) the author's knowledge of world geography in chapters 8-10 was anyhow seriously deficient at many points. It is clear that he was more familiar with the area assigned to Shem than that assigned to Ham or Japhet. Within the area assigned to Shem, his knowledge of Canaan from the Jordan to the sea is the greatest. Despite the fact that many place names have been corrupted in the transmission of the Ethiopic text, scholars have been able to reconstruct some of them. It is possible that the author of Jubilees could have had a detailed knowledge of many cities and towns within ancient Canaan and only vague information on the other parts of the world.

Alexander (1997) tried to understand the Jubilees map in terms of its function. For Alexander (1997:149) this map was first and foremost "a political statement", "... a political gesture of great symbolic significance" (Alexander 1997:151). Linking Jubilees to the second century BCE Alexander is of opinion that the author used his map for polemical purposes to support aspects of the political propaganda of the Hasmonean state (cf Alexander 1997:153).

Jubilees took up known cartographic forms of the Greek mythological tradition in a standard Ionian map and used it to polemise against contemporary Greek claims that Delphi is the omphalos of the world. He stated that it is rather Jerusalem that indicates the navel of the earth. Alexander made two statements that would be important in later research. First he said that maps "even modern scientifically surveyed maps, are ideological constructs" (Alexander 1997:151, emphasis added). Secondly he assigns this polemic to a Hasmonean redefinition of "the concept of Jewish territoriality, the relationship of Israel to the Diaspora, and possibly even the concept what it meant to be a Jew" (Alexander 1997:151). Identity and ideology conceptualised in spatial terms are the key words in Alexander's words.

Frey (1997:282) refers to the "geopolitische Interesse des Jubiläenbuchs". VanderKam (2000:66) refers to "politico-religious ends". According to VanderKam (2000:47) we have here "a scheme that while it 
echoes historical and geographical facts, serves a larger end". ${ }^{9}$ We are dealing here with "ideological cartography as practiced by one learned writer" (VanderKam 2000:47). Behind these references to historical times, orientation of places, and numbers there is "ein sehr konkretes geschichtstheologisches und geopolitisches Interesse" (Frey 1997:266). These chronologic and topographic constructs are "komplexe Symbolsysteme, die ihren Rezipienten durch die Mitteilung raum-zeitlicher Orientierung nicht nur ein Bild der Welt und ihres eigenen Platzes im Weltgefüge, sondern zugleich auch Wertsetzungen und Sinnstrukturen vermitteln und so zur Identitätsfindung und -sicherung beitragen wollen" (Frey 1997:261) (emphasis added).

The ultimate purpose of the map presented in Jubilees 8:10-9:15 is more than mere spatial-chronologic orientation of the recipients. In the final run it is an effort to circumscribe the real identity of those to whom the author of Jubilees belongs. To put this in perspective some of the influences that contributed to this ideological viewpoint have to be studied next.

\section{JUBILEES AS A TRAJECTORY IN JUDAEAN THINKING}

The Jewish geographic lore found in the book of Jubilees, probably coming from the Second-Temple period, represents a "trajectory of an important tradition from its OT and Jewish roots ..." (Scott 2002:171). The design used in Jubilees is probably based on two traditions. The world depicted in terms of three areas with a favourable allotment for Shem-Israel was probably influenced by a Noah tradition as well as boundary texts in the Old Testament . The description of these areas in terms of their boundaries was formed by the amalgamation of these different indications of the boundaries of the territory of old Israel.

\subsection{The "Book of Noah"}

Fragments of the Aramaic scroll of the Genesis Apocryphon (1QapGen 16-17) found in Cave 1 in 1955, "contain a very similar description of the distribution of the earth among the sons of Noah" (Scott 2002:28). Of the twenty-two columns of the Apocryphon it was possible to decipher the largest part of five columns. The narrative in columns 16 and 17 of the Apocryhon describes Noah's division of the land among his sons and their distribution of their portions to their sons agreeing with Genesis 10 and its rendition in Jubilees

\footnotetext{
${ }^{9}$ Frey even sees the geographical information as disarranged. The climatic indications as cold, hot, temperate of the three divisions of the earth shows "dass der Autor mit seiner Darstellung ein idealtypisches Bild zeichnet, das der Wirklichkeit in wesentlichen Punkten nicht entspricht, sondern andere Ziele verfolgt" (Frey 1997:283).
} 
8:10-9:13. A comparison of Jubilees and the Genesis Apocryphon indicates to us that the author of Jubilees not merely composed new sections, but used "traditional material which came to him in either written or oral form" (Wintermute 1988:37). Whether the Genesis Apocryphon and Jubilees reflect two versions of the same tradition or the parallel development of an older, probably a Noah tradition, ${ }^{10}$ is not sure..$^{11}$

The theory of an influential Noah tradition is partly based on the reference in Jubilees of a "book". Jubilees 8:11 refers to "the writing from the bosom of their father Noah." Jubilees 10:13-14 also refers to the "book" of Noah. The lots in Jubilees 8-9 are described according to the way they are indicated in this book. In the Third Sybil from the second century BCE, originating from Alexandria of Egypt and thickly overlayed with Greek mythology, three sons are also assigned portions by lot, being held inviolable by an oath imposed by their father. If these apportioned lots are changed it would bring a curse upon its offender and divine judgement. From this comparison Scott (2002:36) came to the conclusion that a Vorlage of Jubilees 8-9 existed and circulated independently during the Second Temple period. This "Book of Noah" referred to in Jubilees 8-9 also circulated in Alexandria, Egypt, the place where the Third Sibyl originated and later the Alexandrian World-Chronicles as well (cf Scott 1997:377-8). ${ }^{12}$

\footnotetext{
${ }^{10} \mathrm{~F}$ Garcia Martinez in his "4QMess Ar and the Book of Noah" in his Qumran and Apocalyptic: Studies on the Aramaic Texts from Qumran (SJTD, 9; Leiden: Brill) proposed that there was a "Book of Noah". A fragment of the last section of this theoretical book is found in Jubilees 8-9 and in the Genesis Apocryphon cols xvi-xvii. According to his theory they are two independent witnesses to the Book of Noah (cf also Scott 1997a:371).

\begin{abstract}
${ }^{11}$ The debate still continues whether Jubilees is dependent on the Gen Apocryphon or vice versa, or whether both are dependent upon a common source (cf Scott 2002:28). Following $\mathrm{F}$ Garcia Martinez's theory on a Noachic book, Scott (1997a:375) proposes that Jubilees 8-9, concentrating on the division of the earth among Noah's sons with an apocalyptic agenda, indicates the contents of a more narrowly focused "Book of Noah". This smaller book later circulated independently in the Diamerijmoj Ghj (Division of the Earth) tradition, found i.a. in Hippolytos' Chronicron and the Alexandrian World-Chronicles.
\end{abstract}

\footnotetext{
${ }^{12}$ Scott (1997b:303) indicates that not only did Jubilees 8-9 and other Jewish texts from the Second Temple period used the contents of an apocalyptic-oriented book purportedly written by Noah, but that this "book" was also used by Christian writers who had apocalyptic concerns. Hippolytus of Rome's (cf 170-236 CE) work Diamerimos is an example of this further Wirkungsgeshichte. Having a special affinity for Essene/Qumran tradition he used the Noah tradition to counter contemporary apocalyptic orientations indicating that the final judgment of the nations, also indicated in Jubilees 8-9, is still some way off. Using Jubilees as Vorlage Diamerismos preserved the geographical details but deviates, especially in its second part, substantially in order of presentation and of material included from its source. The origins of the nations, and especially the anticipation of their eschatological judgment, was used in apocalyptic oracles against the nations since the second century BCE. In the case of the Diamerismos this information was applied to the end of the Roman Empire and the coming judgment to dampen imminent expectations of the end of the "Kittim" (=Rome) (cf Scott 1997b:319).
} 
Evidence that this "book" was in circulation before the Maccabean crisis also comes from the War Scroll (1QM). In the War Scroll the division of the earth among Noah's sons is used to describe the plan for the final eschatological war against all nations in terms of the sons and grandsons of Noah. It expresses an expectation of eschatological divine judgment by fire and sword (cf Scott 1997:380). A last major offensive is to be launched according to $1 \mathrm{QM} \mathrm{col} 11, \mathrm{II}, 10-14$, based on the order given in Genesis 10:1f, against the sons of Shem, next the sons of Ham in their dwelling places and finally against the sons of Japhet.

This book eventually found its way into the Jewish magical book Sefer ha-Razim (cf Scott 2002:36).

The "Book of Noah" was reused in apocalyptic oracles against the nations, and particularly against the "Kittim". The book recorded the division of the world among the sons and grandsons of Noah after the flood, detailing the inviolable boundaries between the portions, which the children of Noah swore they would never trespass (cf Scott 2002:171-172). Unlike the "book" of Noah to which 1QapGen 5.29 refers, the "book" in Jubilees 8:11, 12 does not record Noah's autobiography, but rather a title deed drawn up by Noah for distributing land among his sons which is analogous to the distribution of the promised land among the twelve tribes (cf Scott 2002:33).

Although Scott (2002:196) admits that this idea of a book could also have been a fiction of Jubilees, one should at least ask what circumstances could have prompted the writing of such a book, perhaps as early as the third century BCE. The period of imperialistic expansion under Antiochus II (ca 223$187 \mathrm{BCE}$ ), when Palestine became a political football between two rival powers in the eastern Mediterranean area, could have been the occasion of such a writing. The perceived infringement of the Ptolemies and then Seleucids on the inherited land of Israel may have sparked a strong reaction from a nationalistic author against these actions. The Noah tradition could have played no small role in the persuasion that Israel's identity was determined by the area allotted to them.

\subsection{Boundary texts in the Old Testament}

Another strategy used by Jubilees to indicate the different areas of the world is by drawing the exact borderlines of each allotted region. These borders are extremely important for Jubilees. Especially the boundaries of the land allotted to Shem in Jubilees 8:12-21 are unique. No Old Testament text describes the extent of the land in precise the same way. Scott $(2005: 190)$ infers that the individual elements of the description in Jubilees are probably drawn from several boundary texts in the Old Testament. Lebanon as constituent of the 


\section{Space, time and group identity in Jubilees 8-9}

land was influenced by the indications of boundaries in Deuteronomy 1:7, 11:24; Joshua 1:4 and 13:1-6. Lebo-Hamath as northernmost boundary of the land was influenced by the information in Numbers 13:21, 34:7-9; Joshua 13:1-6; 1 Kings 14:25; Ezekiel 47:15-17 and Amos 6:14. Egypt as southernmost boundary of the land was influenced by the references in Numbers 34:3-5; 1 Kings 5:1, 8:65 and Ezekiel 47:19. The Mediterranean Sea as westernmost boundary was in indicated by Exodus 23:31; Numbers 34:6; Deuteronomy 11:24; Joshua 1:4 and Ezekiel 47:20.

It is particularly Jubilees' northern and eastern borders of the land that is unparalleled in any other single text (cf Scott 2005:193). Jubilees does not exclude Transjordan from the allotted land. This means that Jubilees regards not only Cisjordan as constituting the land, but Transjordan as well. In close relationship to the Genesis Apocryphon (1 QapGen 21:10-12, 15-19) Jubilees provides a formal description of the boundaries of the land based on God's promise to Abraham in Genesis 15:18-21. He wanted to portray the land as a Garden of Eden and rewrote the two boundary texts of Genesis 10:19 and Genesis 15:18-21 to state his viewpoint. Read together with Jubilees 14:18 and Jubilees 29:2-11, these texts "give us a fairly comprehensive picture of the extent of the Land promised to Abraham" (Scott 2005:201).

In the Bible two divergent maps on the ideal borders of the land are found in Genesis 15:18-21 and Numbers 34:3-12. The Genesis map includes the eastern side of the Jordan and all the land of Syria and Lebanon up to the Euphrates River. The text of Numbers excludes Transjordan, restricting the area to the western side of the Jordan River. In the case of Numbers Israel entered the Promised Land only after they crossed the Jordan. In the case of Genesis, conforming to the views in Deuteronomy that includes Transjordan, the crossing of the Arnon and conquest of the land of Sihon the Amorite, already marks the beginning of the conquest (cf Dt 2:24-25).

In mentioning Lebanon and Hamath Jubilees includes extensive territory to the north and the east as part of the land of Israel and sides with texts like Ezekiel 47:15-20 that deviates from the biblical tradition that restricts the Land to Cisjordan. Transjordan is part of this Promised Land. The mere occurrence of the toponym Hamath, although it is not exactly indicated where it is located, "shows that the northern boundary of the Land is very much a concern for the Book of Jubilees" (Scott 2005:193).

The book of Jubilees uses this "maximalist perspective" (Scott 2005:193) to establish Israel's ancestral right to the land. Jubilees probably derived his view from the Song of Moses where it is stated that God established Israel's right to the Land during the original division of the world among the nations (Dt 32:8-9). In the eschatological expectation of the Book 
of Jubilees the land of Israel plays a central role. There seems to be a connection in his mind between violation of territorial boundaries and the future divine judgement by sword and fire (cf Scott 2002:35.)

When Israel finally repents of its sinful ways the period of restoration will commence with the return of the exiles to the Land, at "year zero" in the countdown to the culmination of the restoration 2450 years later at the second jubilee of jubilees (cf Scott 2005:206). At that occasion the true borders will be properly noted. Israel will be pushing the borders back to their maximum extent in accordance with the promise to Abraham in Genesis 15:18-21. The original conquest of Canaan is a model for Israel's eschatological return. Jubilees 49:18-19 provides a likely scenario of the events that lead up to the rebuild of the temple. "On this model, the Israelites of the restoration era will first enter the Land, take possession of it from the foreigners who currently occupy it, set up the tabernacle in the middle of the Land, and then rebuild the Temple on that site" (Scott 2005:207).

\section{SPACE AND TIME IN THE BOOK OF JUBILEES}

It is clear from this last paragraph that Jubilees links space to his time scheme. The allotted land with its promised boundaries will come to realisation at the end of the fiftieth jubilee. The spatial orientation in Jubilees 8:10-9:15 is to be read in terms of the time schedule of the rest of the book with its chronological system of jubilees and heavenly space. According to Scott (2005:161-162) the goal of history in Jubilees is to bring sacred space into conformity with sacred time in accordance with the foreordained divine will so that everything will become "on earth as in heaven" (cf also Scott 2005:208). Concepts of time are used hand in hand with concepts of space. The world history is marked off in terms of jubilees (fifty year units). World history runs from creation to re-creation. The restoration of Israel is symbolized by the repristination of Zion. In the new creation Eden-like conditions are expected to prevail. At the jubilee of jubilees, the fiftieth jubilee from the creation, Yahweh will redeem Israel from Egypt and return his people to their rightful land. Jubilees not only presents us with a mental "map" of the whole world with its inviolable boundaries of the nations, but also outlines the whole history of the world in terms of units of jubilees from beginning to end (cf Scott 2005:73-74).

At the time of restoration, culminating in the new creation and the establishment of the eschatological temple in Zion, all times and places will be brought back into conformity with the Creator's will as foreordained in the heavenly tablets (cf Scott 2005:162). A new era will dawn "as an outflow of the 
re-established harmony between sacred space and sacred land" (Scott 2005:207-208). This final culmination of the restoration will come about in the distant future. The intervening years between creation and re-creation are expected to be progressing incrementally towards that final consummation.

Everything is gradually restored to its original, pristine condition in accordance with the original intended divine will inscribed on the heavenly tablets (cf Scott 2005:178).

In this process the land plays an important role. It is the scene where the covenant relationship between God and his people will be lived out in the age to come. The temple plays an important role. In Jubilees 8:19 Jerusalem is the omphalos (navel) of the earth - an interpretation of Ezekiel 38:12. Jerusalem and the land together form the sacrosanct place of divine favour and the position from which the world will ultimately be brought under subjection. It is also important for Jubilees to ascertain the borders of the ideal land. Israel will not conquer a land that rightfully belonged to another nation, they will only be taking back territory that was theirs all along (cf Scott 2005:177). The ultimate realignment of sacred space with sacred time will depend on it (cf Scott 2005:209).

\section{SPACE, TIME AND IDENTITY}

There is, however, also a third aspect to Jubilees' construction. The use of time (jubilee units) and space (land) must be linked to the society and its identity. Referring to the notion of territoriality, Sack (1986:216) remarks that referring to space in terms of territoriality "provides an essential link between society, space, and time". Soja (1996) in his study of "Thirdspace" combined historicity, sociality and space into a triple dialectic. Soja (1996:3) indicated a "growing awareness of the simultaneity and interwoven complexity of the social, the historical, and the spatial, their inseparability and

interdependence". Using the formula "Trialectics of Spatiality", Soja (1996:53f) explains that the use of spatiality along with historicality and sociality implies that space can not be used in absolute terms to indicate mere physical place. The concept space should become part of the dialectic of the lived and the conceived, the "real" and the "imagined", the material world and our thoughts about it (cf Soja 1996:61). Physical space, also called "perceived space" or "First Space", is always linked to the representation of that space ("conceived space" or "Second Space"), and to the ideology according to which that space is experienced ("lived space" or "Third Space"). In the same way historicity is not mere chronological measurement in terms of hours and years, but conceptualised time linked to ideology. Space and time in turn are always linked to the ideology one holds on a specific society and their identity. 
Sack (1986) uses the notion "Territoriality" to understand how society and space are interconnected with each other. There is more to territoriality than the simple descriptions of the geographic extent of human activities in space. It is "a spatial strategy to affect, influence, or control resources and people, by controlling area" (Sack 1986:1). For Sack (1986:19) territoriality is "the attempt by an individual or group to affect, influence, or control people, phenomena, and relationships, by delimiting and asserting control over a geographic area".

By studying the use of territoriality in a society it becomes possible to analyse the perspectives of those controlled and those doing the controlling, whether they be individuals or groups (cf Sack 1986:21). While geography studies cultural activities in terms of locations and orientations, the study of territoriality goes further to do research into social structures, and the way space is used as strategy to control interrelationships. Defining territory is a way of transmitting energy and information in order to affect, influence, and control the ideas and actions of others and their access to resources. Spatial relations are the results of influence and power. Geographical organization presupposes the maintenance of different degrees of access to people, things, and relationships (cf Sack 1986:26).

Societies use different geographical organizations and various conceptions of space and place. As societies change, geographical landscapes and meanings also change. While primitive societies are egalitarian, civilised societies have elites or "classes" who control society. In the transformation from primitive to civilised societies "elites arose indigenously and combined a religious with a redistributive role" (Sack 1986:67). In this regard Sacks (1986:77) refers to societies in which the religious elite (as in Jubilees) plays a leading role. In these societies

... the more abstract calendars and maps of imperial officials were ladened with mythical-ritualistic meanings. Calendric systems of empires had astrological overtones. Priests were the reckoners of time, and time was reckoned to keep the empire in harmony with the heavens. Symbols of geographic space played an especially important role in establishing imperial harmony. Space was given mythical content.

In Jubilees physical terrestrial sites are depicted in terms of demarcated territories and sacred space. This function together with a heptadic presented history to form a theology addressed to the readers of the Book of Jubilees. Together space and time serves as propaganda for a social community keeping the law and the directives for the holy days. Space, time and society 


\section{Space, time and group identity in Jubilees 8-9}

together form the ideology the author advances for his compatriots of probably the second century BCE Palestine.

\section{SACRED SPACE}

Applied to the contents of Jubilees 8:11-9:15, these theories on the interrelationship of society, space, and time illustrate the author's view on Israel's real identity. In Jubilees physical terrestrial sites are depicted in terms of demarcated territories and sacred space. This function together with a heptadic presented history to form a theology addressed to the readers of the Book of Jubilees. Together space and time serves as propaganda for a social community keeping the law and the directives for the holy days. Space, time and society together form the ideology the author advances for his compatriots of probably the second century BCE Palestine.

We next go into more detail of this triade of space, time and society in Jubilees. Scott $(2005: 8)$ indicates the "rigorous symmetry between the temporal and spatial axes in the space-time continuum" as a distinctive characteristic of the book of Jubilees. There is a "temporal and spatial symmetry" (Scott 2005:9) in the Book.

According to Scott (2005:8) "The ultimate goal of history for Jubilees is the complete restoration of sacred time and sacred space, so that what is done in the earthly cultus in the Land of Israel exactly corresponds to the way that things are already done in the heavenly cultus, that is, in accordance with the will of God from creation as inscribed on the heavenly tablets." For Jubilees earth should perfectly mirror heaven and Endzeit should recapitulate Urzeit.

Investigating the integral relationship between sacred space and sacred time in Jubilees, it becomes clear "how the book constructs a spacetime continuum that aims at a coherent and comprehensive whole by the time of the culmination of human history" (Scott 2005:15). This expected synchronization of cultic practice in heaven and on earth operates first and foremost in the land of Israel.

In Jubilees 8:17-19 three sacred places are located in the territory allotted to Shem. They are the Garden of Eden, Mount Sinai and Mount Zion. These places are depicted as forming the navel of the earth facing one another. The Garden of Eden is one of the holiest places, depicted as such in Jubilees 3:9-10 and 4:23-25 foreshadowing Jubilees 8:17-19 where the Garden is part of Shem's patrimony. Mount Hermon next to Mount Zion acts as sacred centres. Zion is mentioned in Jubilees 1:29, 4:26. In Jubilees 8:19 it is called the "centre of the earth". Jubilees $4: 26$ adds a fourth holy place: mountain of the morning/afternoon, also translated as Mountain of the East. 
For Jubilees 8:17-19 it is important that not only these three sites, but also the mountain Libar and all other sacrificial sites of the patriarchs are found in that section of the earth given to Noah's son Shem. Reference to the moderate territory of Shem as "neither too hot nor too cold" (Jub 8:30) coupled to sacred mountains "are all informed by the notion of axis mundi" (Sulzbach 2005:300). According to Jubilees 7:11f, God will reside in this part of the world. This area forms the centre of the earth. It is the eschatological residence of the Lord. Here "... soll Israel als das geheiligte Volk in dem inm zugewiesenen Land lebene" (Frey 1997:279). Along with the ordering of time as found in Jubilees, this spatial orientation found in particulars of holy sites depicts the "Weltordnung" according to which Israel will find its place and calling among the nations (cf Frey 1997:262).

For Sulzbach (2005:283) the equation of Zion and the Garden of Eden, the absorbing of the prestige enjoyed by Mount Sinai in Mount Zion, ${ }^{13}$ and the interest in both a heavenly and earthly temple service, reveals a stronglytemple oriented focus. Jerusalem is mentioned in Jubilees 7:36, 12:19, 13:16, 29, 25:3, 11, 21, 27:15, 32:1, 35:16, 39:6. The title "Highest God" is linked to Jerusalem, its cult and its priests. Sulzbach (2005:302) therefore calls Jubilees' view point a "nationalist, temple-oriented theology". In promoting this theology the geographical aspects in Jubilees represents a "geo-political or rather a sacred geography" (Sulzbach 2005:286). Not only spatial markers are presented, but also primordial times and sacred sites "that allow a conduit between heaven and earth" (Sulzbach 2005:290). Those sites that facilitate the flow of information from above attain amplified significance. Temples related to mountains are linked with the notion of "centeredness" where the holy place occupies a central place in the physical or ideological landscape. These holy places form the centre of the world and even the universe. This theme is also accentuated by the focus on "synchronised angelic service in the heavenly temple and on earth in the place where God dwells" (Sulzbach 2005:300). This is to be understood against the background of Jubilees' understanding of the unbreakable connection between the descendants of Shem (i.e. the Jewish people), the land and the divine presence in that land among the people.

In line with the probable Noah tradition indicated above, the allotment of the Zion centred area to Shem in Jubilees 8:12, 21, 24, and 29 is depicted as an eternal inheritance (cf Berger 1981:284). The division of the earth is a permanent command eternally fixed by oaths. A geographical interpretation of

\footnotetext{
${ }^{13}$ One of the problems in Jubilees research is this attachment to Zion = Jerusalem. It is presumed from the fragments found among the Dead Sea Scrolls that the Essene groups probably used this book. The theories, however, indicate that the Essenes removed themselves from Jerusalem and established a sectarian centre somewhere in the desert, probably at Qumran (cf Endres 1987:234).
} 


\section{Space, time and group identity in Jubilees 8-9}

the table of nations (Gn 10) is used here in full conformity with the ideological world chronology of Jubilees to indicate the God given unchangeable "geordneten Weltganzen" (Frey 1997:286). Space and time are used here to legitimate Israel's original and unchangeable claim to that area traditionally called Canaan (cf Frey 1997:281).

This construction could have been aimed at direct opposition to the circumstances of the time of the book when ownership of the Palestinian area was in dispute. But there is actually more to it than a contemporary dispute on land. Topographical and chronological information in Jubilees find its real meaning in the motif of the land and holiness (cf Frey 1997:288). Keeping to this eternally ordained chronological and spatial order would contribute to the preservation of Israel's identity as holy elected people. This construction of holy place and holy time make the Israelite reader understand what his/her real identity is as member of a holy and elected people who are to claim the land in which they live as God's eternal heritage.

\section{DEMARCATED SPACE}

As stated above in 5, not only privileged space but also demarcated area played a role in Jubilee's construction. Located holy place according to the Noah tradition was combined in Jubilees with boundary texts to indicate the demarcation of the territory allotted to Israel in accord with Jubilees' chronological scheme. The book of Jubilees evidently holds that the generation of the conquest not only employed a faulty (lunar) calendar, but that they also misapprehended the extent of the land God gave to them. Israel excluded the Transjordan area and "radically erred in its cultic practice from the outset and thereby defiled the Land" (Scott 2005:218). When Israel returns to their land after the exile at the culmination of Jubilees' final jubilee, they will begin to conduct the cultus in harmony with the cultus in heaven. All times and places will then be brought back "into conformity with the Creator's will as foreordained in the heavenly tablets (cf Jub 1:26-29)" (Scott 2005:218).

The exact boundaries of the land will therefore have to be precisely defined for that time. When Noah divided the earth between his sons by lot, an oath was sweared (Jub 9:14-15) that those who transgress these borders will be punished on the day of judgement. The boundaries of all lands were supposed to be inviolable. In the book of Jubilees not only the proper observance of the times and the seasons of the foreordained Sabbatical calendar are of utmost importance, but also the precise boundaries of the land. Jubilees 50:2-3 indicates that in the end both the time as well as the extent of the land will be known when Israel enters the land they are to possess in the end. 
Another reason for emphasizing the boundaries of Israel is "because the whole land is considered Temple land, with the Holy of Holies radiating out in concentric circles to the borders of the Land, beyond which lay the unclean nations round about" (Scott 2005:185-186). Using the Deuteronomic concept of the "holiness of the people", every possible measure had to be taken to stave off uncleanness from the outside and to eradicate it from inside. For this purpose it is important to know the exact borders of the land.

As the author "has special praise for the land of Lebanon from Jordan to the sea (10:29)" (Wintermute 1988:45), he chose for the tradition that gives the land maximal boundaries to the north and to the east (Gn 15:18-21; Deuteronomy). For this purpose the author of Jubilees used geographicalethnological traditions representing the knowledge of his time, the table of nations in Genesis 10 and the cultic presentation of the holiness of Zion and its surroundings to transform the genealogical list in Genesis 10 into a geographical description in Jubilees that serves politico-religious ends (cf Frey 1997:285).

In this he resorted to a technique he often uses in his book. He moved later realities into earlier times. This procedure can be indicated in various areas of the book. Legal concerns, holidays, circumcision, and the like, were all retrojected back into the patriarchal history. The territories of the nations were in his view assigned by Noah with the guidance of an angel of the presence who may have brought Noah a book with details of the national boundaries. Noah is depicted as a kind of cosmic forefather who adheres to the Sinai covenant. The specific territory promised to the patriarchs, the descendants of Shem through Arpachshad, is now retrojected to an initial division of the earth in the pre-patriarchal era of Noah (cf Halpern-Amaru 1994:26). The allotment that falls to the house of Shem (to possess forever) includes the territory that was promised to the patriarchs in the biblical narrative. Within the house of Shem that particular area promised to the patriarchs is now assigned to Arpachshad, the ancestor of Abraham. In contrast to the biblical narrative the land is thus placed within the allotment of the patriarchal progenitor. Jubilees even improves on Genesis by moving the territorial allotments of the Judges back into Genesis 10, to a time before the Bible has made reference to any Canaanite in the land. It seems therefore that the purpose of (re)defining the territory of Israel is firstly the "Legitimation des Landbesitzes Israels, die Abwehr jeder Verwischung der Grenzen und die Bestreitung aller Ansprüche vor fremde ... auf das Land um den Zion." (Frey 1997:285).

Jubilees' geopolitical interests with his reconstruction are at its clearest in his view on the misplaced Canaan who should have lived in the most 
western parts, but are now occupying area against the eternal commands of the area of Shem and placed itself under the damnation for those who transgress God's commands (cf Jub 10:31). The author of Jubilees creates an account of how the land of Lebanon, as far as the river of Egypt, eastward and westward, from the bank of the Jordan and from the shore of the sea, was illegitimately seized by Ham's son Canaan. As all boundaries were fixed by oaths in Jubilees, it becomes clear that Jubilees' geographical presentation is aimed at emphasizing the guilt of Canaan, Noah's grandson. Canaan is cursed in Genesis 9:25. Despite the oath taken by Noah's sons and grandsons and against the urgent advice of his relatives, Canaan took part of Shem's territory. The tale of Canaan's illegitimate seizure of Shem's portion in Jubilees 10:34 accounts for how that land came to be called Canaan. The demarcation of the real boundaries of Shem's territory makes the acquisition of the land in the following patriarchal narratives in Jubilees a rightful return to the area allotted to them, rather than the theological complex claim to a land inhabited by others as is found in the biblical narrative (cf Halpern-Amaru 1994:26).

This way in which Jubilees articulates the unlawful Canaanite usurpation makes one believe that the issue of who really owned Canaan was hotly debated when the book was written (cf VanderKam 2000:66). If the second century BCE is assumed to be the time when Jubilees was written, 14 it is possible that the Jewish people were accused of having unlawfully taking Canaan from its original rightful owners. The geographical demarcation in Jubilees 8-9 "addresses the claim that the jews stole their land from the Canaanites, the supposedly rightful owners" (VanderKam 1997:22 note 83). There are no contemporary sources to prove this statement. It can, however, be deduced from later polemical literature that this issues addressed in Jubilees 8-9 was on the table. This detailed demarcation of Israelite territory therefore aims at asserting Israel's ancestral right to the Promised Land. It is what VanderKam (1985:125) calls "a rather blatant attempt to justify the later Israelite conquest of Canaan". It was rather the Canaanites who occupied land not allotted to them. It was therefore only right that Israel drove the children of Canaan from the land they had stolen from its legitimate owners (cf VanderKam 2000:69).

Depending on the theory when Jubilees was written other explanations can also be given. If the origin of the book lies in Maccabean times during the second century BCE, this spatial demarcation could have been "directed

\footnotetext{
${ }^{14}$ VanderKam (1977:284) holds that Jubilees "was almost certainly written between 161 and 140 BC and probably between 161 and 152 BC." The period 161-152 BCE includes the intersacerdotium (159-152) when either no high priest presided in Jerusalem or the sources have failed to preserve his/their name(s). Before this time the Jewish nation had been ruled by the three Hellenizing High Priests Jason, Menelaus and Alcimus. The "intersacerdotium a period of calendrical struggle would provide a perfect setting for Jub" (VanderKam 1977:284).
} 
against the influences of Hellenism, particularly what is understood to be the tendency of its Jewish adherents to drop the distinctive traits of Judaism in favor of a more accommodating form of religion" (VanderKam 1997:16-19). Using a jubilean chronological system and the spatial concept of demarcated territory, the book of Jubilees is aimed at the separation of the pure chosen line from the impure gentiles. This means the strict segregation of people descending from Seth-Noah-Shem from all others. Boundaries and clearly demarcated territories are set out to keep the true Israel from all others, preventing any intermarriage to occur. In terms of 1 Maccabeans 1:11 national freedom and possession of the land was set as goal for the Judeans subjected to foreign powers who were interested in blending them into the surrounding culture. The writer of Jubilees "articulated a powerful argument for freedom from foreign domination and Judean possession of their own land" (VanderKam 1997:22) in an effort to sustain Israel's unique identity.

This is indeed what Sack (1986:216) means by "territory" as "an essential link between society, space, and time". Demarcated space is used here to control interrelationships. Geographical organization and conceptions of space and place are used by the religious elite to control society and determine their identity. Not only heptadic jubilee units and directives for the observation of holy days, but also space are used here to advance the ideology of the author on who the real Israel is and should be. Identity, chronology and spatiality form the triangle to demarcate who Israel is and should be.

\section{CONCLUSION}

To summarise: the author puts forward his ideas on Israel's real identity in Jubilees 8:11-9:15 by using the list of Noah's descendants in Genesis 10:132. To formulate his ideology he exchanged the use of genealogical concepts in Genesis for spatial concepts in his book. In two interrelated parts (Jub 8:1030 and 9:1-15) he maps out the place in the world and its boundaries God allotted to his people. Rather than trying to reconstruct this area in terms of modern geographical knowledge we should enquire to the function of these geographical indications in Jubilees. The author used an existing Noah tradition and several boundary texts from the Old Testament to construct an ideology on Israel's identity in terms of space, time and society. Using theories on spatiality and territoriality in our investigation it became clear to us that this author aims at persuading his readers to identify themselves with his ideological Israel. Place and demarcated space along with realised eschatological time define their true identity. In the consummation of time during the final jubilee they will find their identity in terms of Jerusalem and the holy land God originally allotted to them. 


\section{Works consulted}

Alexander, P S 1997. Jerusalem as the Omphalos of the world: On the history of a geographic concept. Judaism 46, 147-158.

Berger, K 1981. Unterweisung in erzählender Form: Das Buch der Jubiläen. Jüdische Schriften aus hellenistisch-römischer Zeit, Band II. Gütersloh: Gütersloher Verlaghaus Gerd Mohn.

Endres, J C 1987. Biblical interpretation in the Book of Jubilees. Washington, DC: Catholic Biblical Association of America.

Frey, J 1997. Zum Weltbild im Jubilaenbuch, in Albani, M, Frey, J, \& Lange A (eds), Studies in the book of Jubilees, 261-292. Mohr Siebeck: Tübingen.

Halpern-Amaru, B 1994. Rewriting the Bible: Land and covenant in post-biblical Jewish literature. Valley Forge, PA: Trinity Press International.

Scott, J M 1997. Geographic aspects of Noachic materials in the Scrolls at Qumran, in Porter, S E \& Evans, C A (eds), The Scrolls and the Scriptures: Qumran fifty years after, 368-381. Sheffield: Sheffield Academic Press. (Journal for the Study of the Pseudepigrapha, Suppl Series 26.)

Scott, J M 2002. Geography in Early Judaism and Christianity: The Book of Jubilees. Cambridge: Cambridge University Press.

Scott, J M 2005. On earth as in heaven: The restoration of sacred time and sacred space in the book of Jubilees. Leiden: Brill.

Sulzbach, C 2005. The function of sacred geography in the Book of Jubilees. Journal for Semitics 14(2), 283-305.

Sack, R D 1986. Human territoriality: Its theory and history. Cambridge: Cambridge University Press.

Soja, E W 1996. Thirdspace: Journeys to Los Angeles and other real-and-imagined places. Oxford: Blackwell.

Steinberg, N 1993. Kinship and marriage in Genesis: A Household economics perspective. Minneapolis, MN: Fortress.

VanderKam, J C 1985. The Book of Jubilees, in De Jonge, M (ed), Outside the Old Testament, 111-144. Cambridge: Cambridge University Press.

VanderKam, J C 1997. The origins and purposes of the Book of Jubilees, in Albani, M, Frey, J, \& Lange, A (eds). Studies in the book of Jubilees, 3-24. Mohr Siebeck: Tübingen.

VanderKam, J C 2000. Putting them in their place: Geography as an evaluative tool, in VanderKam J C (ed), From revelation to canon: Studies in the Hebrew Bible and second temple literature, 476-499. Leiden: Brill.

Wintermute, O S 1988. Jubilees (Second century BC): A new translation and introduction, in Charlesworth, $\mathrm{J} \mathrm{H}$ (ed), The Old Testament Pseudepigrapha, Vol 2, Expansions of the "Old Testament" and legends, wisdom and philosophical literature, prayers, psalms, and odes, fragments of lost Judeohellenistic works, 35-142. New York: Doubleday. 